\title{
Review of Evidence between Corporate Governance and Mandatory IFRS Adoption from the Perspective of Agency Theory and Information Asymmetry
}

\author{
Raymond Leung", Joe Ilsever \\ School of Business, University of the Fraser Valley, Canada \\ *Corresponding Author: raymond.leung@ufv.ca
}

Copyright (C) 2013 Horizon Research Publishing All rights reserved.

\begin{abstract}
Prior studies illustrate the issues of agency theory stemmed from the separation between ownership and management. As such, information asymmetry between the agent and principal is the major reason why agent can take advantages from adverse selection and moral hazard, which is the obvious problem in recent accounting scandals. Boards of directors therefore have fiduciary duties to exercise effective corporate governance mechanism to control information asymmetry. We have reviewed the extant literature on whether corporate governance is positively related to more and better disclosure as an attempt to reduce information asymmetry. Also, when IFRS requires more disclosure and IFRS adoption becomes mandatory for many jurisdictions, we examined recent studies on whether firms adopting IFRS with corporate governance regimes can reduce information asymmetry by making themselves more transparent. In general, empirical findings are mixed due to the complex and inter-related nature of corporate governance systems including single-country or cross-country studies, self-constructed or comprehensive corporate governance metrics and whether self-selection and endogeneity can be controlled in modeling.
\end{abstract}

Keywords Information Asymmetry, Corporate Governance, Disclosure, IFRS

\section{Agency Theory: The Nature and Issues}

The extant literature has abundant publications about the theory of agency problem and its empirical question of whether such problem can be mitigated by the quality and effectiveness of corporate governance. Jensen and Meckling, (1976) clearly define the nature of agency problem when a contractual agency relationship is established under which one or more principal(s) engage with another agent who agree to perform certain service or duty on their behalf. Such service or duty most likely will involve delegation of decision making authority from the principal to the agent. However, the agent realizes there is information asymmetry between him and the principal, and both parties opt out to maximize personal benefits. It is possible that the agent will not always act in the best interests of the principal. Recognizing this problem, the principal may want to align his interests with the agents by offering incentives and or incurring monitoring costs designed to limit the opportunistic behavior of the agent.

From the principal's perspective, agency problems arise mainly due to the separation of ownership and operational control of the business. With moral hazard stemmed from information asymmetry, shareholders do not have sufficient information to evaluate if managers have fulfilled their contractual duties. Managers learn how and when to drive maximum utility from control of the firms' operations may entrench themselves and pursue self-serving actions at the expenses of shareholders (Jensen \& Meckling, 1976).

Without the execution of effective corporate governance, recent accounting scandals reveal the magnitude of agency problems happens to damage shareholders' and even the society benefits. A wave of corporate managers' wrongdoings in Enron,Worldcom and Parmalat, for example, have serious problems of trusting the reliability of financial reports and disclosure practices in capital markets. As such, the urgency to reform corporate governance regime by board of directors becomes on the top of agenda (Bauwhede and Willekens, 2008). The Cadbury Report published in 1992 sets out recommendations to the company boards and accounting system to mitigate governance risks and failures. Rather than setting out binding laws and regulations, government regulators from the U.K., Germany and Netherlands and other countries set out a code for publicly listed companies to either comply with, explain publicly why they do not. In doing so, it will let the capital markets decide a set of standards is appropriate for individual companies, and if boards of directors do not meet such expectations, investors may create a market sanction by selling their 
shares.

In order to protect their own and other stakeholders' interests, board of directors, representing the shareholders' benefits, have been called to carry out their fiduciary duties by establishing effective corporate governance mechanisms to control and regulate managers. Prior studies general support for the significant role of corporate governance in reducing the agency costs (Ashbaugh et al., 2004). One way to mitigate problems from agency relationship is to reduce the information asymmetry between managers and investors. Thus, many scholarly studies have enormous contributions to examine what attributes of corporate governance become effective in enhancing the transparency of disclosures, arguing that it is beneficial for the firms to have more and better disclosures, for example, more disclosure may reduce the cost of equity.

To differentiate the level of disclosure, the extant literature also points out the important relationship of information needs between ownership concentration and institutional factors (Adhikari and Tondkar, 1992, Ball, R., 1998, Ball, R. et al., 1998, Salter, 1998, Zarzeski, 1996). Particularly, Zarzeski, 1996 argues that firms with exposure in international sales, even domiciled from a culture with more individualism, more masculinity and less uncertainty avoidance are more willing to disclose higher levels of accounting information due to their international resources dependence. Thus, market-force dependence dominates cultural characteristics in international accounting disclosure practices. Similarly, study conducted by Jaggi and Low (2000) support this idea that due to the variations of legal structures, financial reporting and disclosure practice will not be identical among firms. International evidence was provided that firms in the common and code law jurisdictions exhibit significant differences in information needs of investors due to dissimilar corporate ownership (widely dispersed vs. concentrated ownership), corporate capital structure (equity markets or private lending sources). Consequently, it will exercise discernible effects on disclosure practices of financial information. Therefore, equity owners in widely-dispersed ownership in common law countries will demand much more corporate and financial disclosure than those concentrated ownership, and it will result in more effective reduction of information asymmetry between managers and shareholders. Code law based debt-financing by private lenders, however, have more concentrated equity ownership will depend on private communication between the managers and debt-holders.

\section{Relationship between Corporate Governance and Financial Reporting Disclosure}

Hope and Thomas (2008) hypothesize if managers tend to have incentives to take advantages of their information asymmetry at the expense of shareholders. When U.S. accounting standards do not require multinational firms to disclose geographic earnings, some firms continue to disclose while others don't. The two researchers compare these two groups of companies and gather evidence that non-disclosing firms experience greater expansion of foreign sales but with lower foreign profit margin and lower firm value. Thus, Hope and Thomas (2008) argue that the empirical test exhibit consistent results with the agency-cost hypothesis; which is important for firm shareholders to govern managers' disclosure practice. More importantly, Beyer et al. (2010) do take into account from the extant literature that corporate governance mechanisms managed by the board of directors who may exert significant influences over managers' reporting and disclosure practices. In other words, most prior studies provide evidences that corporate disclosures and corporate governance are complementary to each other in an effort to reduce the information asymmetries between investors and managers.

In addition, due to more professional knowledge and experience, institutional ownership is generally believed to have higher level of corporate governance to managers' disclosure of financial reporting. Healy et al. (1999) argue that institutional ownership is positively related to the level of corporate disclosures, because of the higher demands and pressure exercised by institutional investors.

Therefore, ownership structures appear to gain certain empirical support from prior studies in its significant relationship with the effectiveness of corporate governance (Dwivedi \& Jain, 2005; Gorton \& Schimid, 1999; Klein, Shapiro \& Young, 2005; Krivogorsky, 2006). For instance, using profitability ratios (ROE, ROA and MTB) as the dependent variables calculated from a small European sample ( 87 firms with foreign U.S. registrants during 2000 to 2001), Krivogorsky (2006) argues that (i) those key ratios are positively related the level of relational ownership, and (ii) there are significant relationship between the portion of independent directors on the board and those profitability ratios. However, the sample size is regarded as too small and the sample period only covers two years. While foreign ownership may be an important matter, Gray Meek and Roberts (1995) examine financial reporting behaviour of the annual reports from 116 US and 64 UK multinationals and argue that there are significant differences between internationally and domestically listed multinational corporation, especially with regards to strategic information disclosures.

To integrate corporate governance regime in corporate disclosure in an attempt to reduce information asymmetry, Holm and Scholer (2010) collect sample from a Danish dataset that includes 100 companies listed on the Copenhagen Stock Exchange and examine the key variables that are important to achieve effective corporate governance mechanisms in the following: 


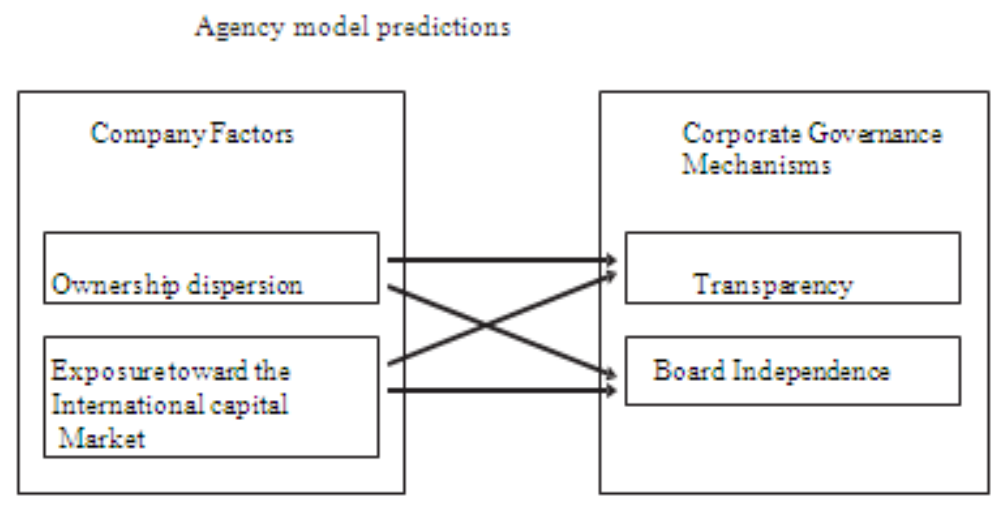

Figure 1. Relationships ExaminedinThis Study

OECD principles ${ }^{1}$ emphasize the importance of transparency in financial reporting and disclosure practice; as the prime corporate governance mechanism to reduce the information asymmetry issue stemmed from the agency problem. Also board independence is important to mitigate the potential conflicts of interest of the board of directors as various corporate governance codes have been associated with the functions of more non-executive directors, especially for the unitary (one-tier) board systems as found in the Anglo-American environments (e.g. Gani \& Jermias, 2006; Klein, Shapiro \& Young, 2005). These two aspects are positively associated with the aspects of ownership dispersion and exposure to the international capital market. Dispersed ownership does not enjoy owner proximity of concentrated ownership, therefore has to depend on high levels of transparency. Meanwhile, international capital market providers would pressure and demand lots of corporate disclosure in order to fully understand the stewardship functions performed by the management.

Holm and Scholer (2010) provides some insights about how ownership structure and international market exposure may impact corporate governance mechanisms, they ignore the importance of other key players such as institutional and legal environment (e.g. mandated disclosure) that surrounding the firm.

Financial reporting is a key practice of corporate disclosure. However, there are multiple factors surrounding the quality of financial reporting. Beyer et al. (2010) argue that the function of corporate information environment is the dynamic interaction as a consequence of information asymmetries and agency problems between investors, firms and managers. Therefore, in a capital markets setting, the corporate information environment is shaped by the decisions made by managers' reporting and disclosure, mandated reporting and disclosures regulations, and analysts'

\footnotetext{
${ }^{1}$ First released in May 1999 and revised in 2004, the Organization for Economic Co-operation and Development (OECD) Principles are one of the $12 \mathrm{key}$ standards for international financial stability of the Financial Stability Board and form the basis for the corporate governance component of the Report on the Observance of Standards and Codes of the World Bank Group.For instance, to achieve the highest sustainable economic growth and employment and arising standard of living in member countries, while maintaining financialstability, and thus to contribute to the development of the world economy
}

expectations. Regarding disclosure regulation, we believe that Beyer et al. (2010) illustrate that the two very important rationales. Firstly, agency costs will be reduced when mandated disclosure allows for more efficient contracting with agents as it can serve as a cost-effective way to commit to frequent and detailed future disclosures when the literature supports that more information can reduce agency costs (e.g. Shleifer and Wolfenzon, 2002). Secondly, economies of scale can be possible since disclosure regulation will result in efficiency gains by reducing investors' duplication of information production and enhance comparability of disclosed information across business and sectors. When financial information users will receive more accurate and timely assessments about firm performances and the optimal level of corporate disclosure, market-wide cost savings and efficiency can be achieved relatively similar across firms(Dye and Sridhar, 2008).

To further support the importance of corporate governance in reducing information asymmetry. Prior studies also investigate if there is any significant association between corporate governance structures and the cost of equity capital. Due to the existence of information asymmetry problem, it is essential to have adequate controls, effective monitoring and transparent financial information for rational investors. Otherwise, investors will price-protect against expected agency cost. As a result, the firm's cost of equity will be effectively increased. It can be resolved by corporate governance's broad spectrum of mechanisms when there is an increase in monitoring managements' actions and limiting their opportunistic behavior. As a consequence, information risk borne by shareholders will be lowered, which lead to reduction of cost of equity. In particularly, Ashbaugh et al. (2004) collect board and committee measures of corporate governance on the Investor Responsibility Research Centre (IRRC) and the Corporate Library that carry governance data on the S\&P 1500 and over 2000 U.S. companies respectively.

When the cost of equity is measured by the average expected return of Value Line's high and low annualized over three $t$ five year horizon, the empirical results show that firms with more independent audit committees and board members and more dispersed ownership are negatively 
associated with the cost of equity ${ }^{2}$.These results also illustrate that both firm and country-based corporate governance structures are complementary, instead of substitutes, to each other. However, the study of Ashbaugh et al. (2004) has the similar self-selection sampling issue as other prior studies when there are only U.S. based samples are taken as the U.S. is highly regarded as a jurisdiction that equips with relatively high level of corporate governance both in firm and country levels.

\section{Corporate Governance and Mandatory IFRS Adoption}

So far, theoretically, the information asymmetry between managers and investors may be mitigated when the extant literature, in general, supports the argument that corporate governance mechanisms, if managed and implemented appropriately, are positively associated with the levels of corporate disclosure including financial reporting. Meanwhile, disclosure regulations may be also beneficial to further enhance the transparency in financial reporting. Since early 1970's major developed economic countries endeavor to establish International Accounting Standards Committee (IASC) and develop a set of globalized accounting standards, namely International Accounting Standards (IAS), which will be commonly adopted by all nations ${ }^{3}$.

After many years of improvements on the IAS, an important milestone was achieved in 2000 when the International Organization of Securities Commissions (IOSCO) endorsed and recommended the IAS to securities regulators around the globe (IOSCO 2000). Later on, the IASC was given more resources, strengthened and reformed to become the International Accounting Standard Board (IASB) with the mandate to further develop the IAS into International Financial Reporting Standards (IFRS). In an effort to formalize and promote IFRS to countries of different jurisdictions, IASB has been closely working with many local accounting regulators and harmonize IFRS with the local accounting standards.

As a result, many countries have gradually mandated the adoption of IFRS to replace their local Generally Accepted Accounting Principles (GAAP). Since then, there are more than 100 countries adopted IFRS as their accounting standards because global accounting regulators agreed to develop a single set of high quality standards that are universally accepted so as to provide better information and comparability to investors and other users (Barth 2006).

The question is, if corporate governance mechanism positively associate with the financial reporting quality when IFRS is adopted?

\footnotetext{
${ }^{2}$ The cost of equity by Ashbaugh et al. (2004) is calculated from the expected return of the average of Value Line's high and low annualized expected return over a three to five year horizon. It is the discount rate that equates firms' three to five year target price forecasts and dividend forecast to a firm's current prices.

${ }^{3}$ The participating countries for establishing the IASC include Australia Canada, France, Germany, Japan, Mexico, Netherlands, the UK/Ireland and the U.S.A.
}

The two schools of thoughts for mandatory IFRS Adoption: Pro-quality vs. Pro-incentives debate.

When IFRS adoption is mandatory in the E.U., where is regarded as an unique research settings which provides researchers opportunity to examine whether it is the high quality of accounting standards and/or prepare incentives drive accounting quality and subsequent economic consequences. In particular, the E.U. is a combined area of both shareholder-based common law countries and stakeholder-oriented code law jurisdictions.

The literature, on average, supports the pro-incentives side.Voluntary adoption of IFRS: need more incentives such as need for equity investment and international exposure of business to adopt IFRS as it is done by the firms without the mandate.

However under mandatory I FRS adoption: even though everyone has to do it, it needs MORE incentives for firms to ACTUALLY commit to full compliance, more and better disclosures, fair values reporting with transparency. Based on the nature of opportunistic behavior of managers who are just the agents for the firm, he may not commit himself even though it is good for the company. Thus, even though the better tool (i.e. IFRS, a higher quality of accounting standard) is given already but the operator may not be willing to devote himself in fully utilize the tool (i.e. without strong incentives).

To ensure that managers are fully compliant with IFRS with strong reporting incentives, shareholders have to protect their own benefits from more transparent financial reporting by exercising a better and established corporate governance mechanism as a tool to regulate, monitor and control managers' behavior. The proponents include a recent study by Verrest et al. (2010) who gather a small sample of 223 European listed mandatory IFRS adopting firms from the MSCI Pan Euro Index and examine if firms with strong internal (i.e. firm-specific) corporate governance structures such as effective audit committees will engage in more substantial disclosures about IFRS effects on key financial statement variables such as net income and equity value. As expected, the researchers undertake regression analyses and illustrate empirical evidences that stronger governance firms both disclose more transparent financial and non-financial information, comply better with IFRS adoption. More importantly, strong governance firms use the timing adoption flexibility in a conservative fashion while weak governance counterparts tend to employ certain IFRS disclosure standards in an opportunistic fashion.

Thus, study of Verrest et al. (2010) displays an important argument that the need for disclosure arises from information asymmetries between managers and investors in IFRS adoption. In addition, extant literature also favors the debate for greater disclosure of corporate information should reduce the cost of equity which stemmed from the substantial levels of information asymmetries (Leuz and Verrecchia, 2000; Lambert et al., 2007) When adverse selection practices may be benefitting managers at the expense of shareholders, regulated disclosures, including mandatory IFRS adoption, 
will be able to reduce such negative impact (Diamond and Verrecchia, 1991). However, since IFRS is a set of principle-based accounting standards that is still subject to high level of professional judgment of managers, it is still an open question for managers who may or may not exercise their full commitment in adopting IFRS. In other words, enhancements of reporting quality from practicing "serious adoption" of IFRS compliance is conditional to their reporting incentives (Daske et al., 2008).

The important point here is to illustrate that even though mandatory IFRS adoption requires more disclosures to achieve transparency of financial reporting from firms, agency problems arise from separation between ownership and control that maintaining certain extent of information asymmetry may still exist ${ }^{4}$. As a result, when board of directors, who represent shareholders' interests, are more than willing to adopt IFRS regulations for achieving capital market benefits, financial reporting and disclosure practices are still carried out by the managers who may have opportunistic behavior. To mitigate this problem, the literature primarily collect evidences to support the important role of institutional factors such as legal and enforcements (e.g. Ball et al., 2003), firm-specific internal corporate governance structures are essential to monitor and regulate managers so that strong reporting incentives will ensure high quality of information be disclosed and subsequent capital market benefits can be realized from IFRS adoption.

Aksu (2006) studies the impact of strong local corporate governance principles along with the voluntary adoption of IFRS on the transparency and disclosure level (proxied by the T\&D Index scores) for a sample of 52 large firms listed on the Istanbul Stock Exchange. The study finds that the T\&D Index scores improve when firms adopt IFRS voluntarily, indicating their commitment to such best practice in corporate governance. Similar to the Lopes and Walker (2008) study of Brazilian firm earnings quality, Turkey provides another example of a developing country with an inherent need for external capital. However, the Asku study's sampling period of two years is too brief, the study only focuses on a single country sample (i.e. Turkey) without controlling for the potential self-selection issue in voluntary IFRS adoption.

Examining the effects from firm-specific factors, Durnev and Kim (2005) argue that firms with three attributes (investment opportunities, external financing and ownership structure) are positively identified with the quality of corporate governance and disclosure practice. More importantly, Durney and Kim document that good investment opportunities provide more incentives for firms to improve their internal corporate governance mechanisms, even domiciled in countries with weaker legal frameworks. While legal institutional factors matter for corporate

\footnotetext{
${ }^{4}$ The study of Berie and Means (1932) argues that when shareholders' ownership separates from management's control, managers' financial reporting and disclosure practices may be controlled by their opportunistic behavior for personal gains at the expenses of shareholders.
}

governance practices (La Porta et al., 1998), this study indicates that firms with strong incentives seem to adapt to poor legal frameworks to develop efficient internal governance regimes, resulting in greater positive correlation with the valuation of firms in stronger legal regimes. This implies that even though a strong legal institution is important when the magnitude of the legal framework and firm values are positively related, the positive relation becomes insignificant when transparency and governance scores are included in the regression model. Their study indicates that strong firm motivations are important in creating better governance and disclosure practices in weak legal environments. That internal corporate governance dominates the institutional environment has been noted by Hail and Leuz (2006) whose empirical findings show that the cost of capital reducing effects in countries is significantly associated with extensive disclosure requirements, but not with strong securities regulation and stricter enforcement regimes.

To protect shareholders' interests against improprieties in mandatory IFRS adoption, it becomes important to monitor internal corporate governance and oversee management behavior. This monitoring requires independent board members with financial expertise to control the audit committee and remuneration committee, separation of duties between the chairman and $\mathrm{CEO}$, and good risk management and control. Therefore, a broad assessment index including comprehensive internal corporate governance is important to measure the board of directors' commitment to mandatory IFRS adoption.

When reporting incentives of mandatory IFRS adoption is regarded as an important condition for implementing high quality of financial reports and disclosures, corporate governance structures can be viewed as a set of monitoring mechanisms to align the interest of managers (agents) with shareholders (principals) in an attempt to mitigate agency costs (Rezaee, 2009). Moreover, Soderstrom and Sun (2007) gather significant results to prove that the interaction between both the institutional settings and market force can shape managers' reporting incentives. Complementarily, both firm-specific internal and nation-wide external corporate governance mechanisms work together to jointly shape managers' reporting incentives to achieve transparency in financial reporting for the best interest of shareholders (Shan and $\mathrm{Xu}, 2012$ ).

On the other hand, a recent study by Liang and Shan (2013) who proxy managers' incentives by the effectiveness of self-constructed corporate governance score and examine the effects on earnings quality (proxied by accruals quality). According to their regression analyzes, earnings quality has improved in the post-mandatory IFRS adoption period, but it is conditional upon the institutional settings. From the sample from Germany, stakeholder-oriented economies show that governance mechanisms and high quality standards function as partial complements in financial reporting. From the sample from the U.K., it exhibits that when such a high quality of accounting standards as IFRS is 
mandated, the significance for effective corporate governance mechanisms is reduced, which suggests that both high quality of accounting standards and corporate governance operate as substitutes to each other.

Table 1 depicts and summarizes the direction of the above-mentioned key research studies on their topics, research subjects, relationship between dependent and independent variables in the models, samples and important proxies, as well as the results. It highlights the fact that corporate governance scholars gradually conducted research with more sophisticated and vigorous research models and design on the effects from disclosures, to corporate governance variables and then IFRS adoption on reducing information asymmetry between investors and managers.

In sum, this review exercise comes to realize that corporate governance is a highly complex and interrelated concept which can be analyzed from accounting, finance, economics and legal perspectives. Numerous research studies have attempted to prove that sound corporate governance structure is the foundation of the firm's long-term success, because there are significant reductions of information asymmetry. In general, the literature supports the argument that corporate governance mechanisms are important in mitigating agency cost and enhancing transparency in financial reporting with mandatory IFRS adoption. However, we also notice that there are mixed results from both examining the link between disclosure and the firm's cost of capital; and from testing to the association between corporate governance structures and the benefits from more transparent financial reporting. The major reasons may be stemmed from using samples from whether the single- or cross-countries basis. Also, the empirical test results depend on the disclosure and corporate governance metrics (either self-constructed or comprehensive scoring database), benchmarks for comparison and research design used.Moreover, few studies control explicitly for self-selection and endogeneity issues in research models (Leuz \& Verrecchia, 2000).

Therefore, to improve the future avenues of research in corporate governance in relation to mandatory IFRS adoption, it is required to have a well-thought sample size and research methodology, understand the limitation of scope and select the appropriate benchmarks for comparison. 
Table 1. Summary of key research studies of the effects from disclosures/IFRS adoption to reducing information asymmetry

\begin{tabular}{|c|c|c|c|}
\hline Studies by & $\begin{array}{c}\text { Independent (IV) and dependent variables (DV) of Corp. } \\
\text { Gov./Disclosure Metrics }\end{array}$ & Sample/Methods/Models & Empirical Results \\
\hline $\begin{array}{c}\text { Zarzeski (1996) } \\
\text { Disclosures/IFRS } \\
\text { Examine the effects of culture \& } \\
\text { market forces on accounting } \\
\text { disclosure practices }\end{array}$ & $\begin{array}{l}\text { IV's: Market Forces: Foreign sales/total sales, total } \\
\text { debt/total assets, natural log of total assets } \\
\text { Cultural Forces: Uncertainty avoidance, Individualism vs. } \\
\text { Collectivism, Masculinity vs. Femininity \& Power } \\
\quad \text { distance. } \\
\text { DV's: Both required and voluntary disclosure items in } \\
\text { annual reports from seven countries that used to construct a } \\
\text { comprehensive weighted scoring system. }\end{array}$ & $\begin{array}{l}\text { To match with this study of cultural diversity, random } \\
\text { sample is selected from Compustat Global Vantage } \\
\text { (1990) or the IBES (1986-1992) comprising small, } \\
\text { medium and large firms, by size of revenue, across six } \\
\text { industries from seven industrialized countries: France, } \\
\text { Germany, Hong Kong, Japan, Norway, the U.K. and } \\
\text { the U.S. } \\
\text { From } 795 \text { requests of annual reports, } 266 \text { received (i.e. } \\
33 \% \text { ), and finally } 256 \text { provided information needed for } \\
\text { this study. OLS regression models were used to } \\
\text { develop International disclosure (dependence) model } \\
\text { for the DV (IV). }\end{array}$ & $\begin{array}{l}\text { Firms with higher foreign sales (greater dependence on } \\
\text { debt financing) are more (less) likely to disclose higher } \\
\text { (lower) levels of investor-oriented information due to their } \\
\text { higher (lower) level of international resource dependence. } \\
\text { More importantly, when firms are more internationally } \\
\text { dependent, their disclosure behavior is different from their } \\
\text { home culture. }\end{array}$ \\
\hline $\begin{array}{l}\text { Jaggi, B. and P.Y. Low. (2000) } \\
\text { Examines the impact of legal } \\
\text { systems on financial disclosures by } \\
\text { firms in different countries }\end{array}$ & $\begin{array}{c}\text { DV of financial disclosures is taken from International } \\
\text { Financial Reporting Index (IFRI) for Industrial Companies } \\
\text { developed by International Financial Analysis and } \\
\text { Research (1993). IFRI based on the mean disclosure scores } \\
\text { of } 90 \text { items on a sample of largest industrial firms (Salter, } \\
\text { 1998) that divided into seven categories from the financial } \\
\text { statements. } \\
\text { IV's are (i) cultural values from countries that measured by } \\
\text { Hofstede (1984); (ii) legal system variable is coded as a } \\
\text { dummy of one (zero) for common (coded) law countries } \\
\text { from La Porta et al. (1996). } \\
\text { Other variables include total assets (firm size), debt ratio, } \\
\text { market capitalization, etc. }\end{array}$ & $\begin{array}{l}\text { Based on } 1991 \text { financial data retrieved from the Center } \\
\text { for International Financial Accounting Research } \\
\text { (1993), \& country's cultural values developed by } \\
\text { Hofstede's study (1984). After the screening, 505 } \\
\text { firms from } 28 \text { countries were obtained from Global } \\
\text { Vantage database. Based upon the sample, the } \\
\text { regression model was developed. }\end{array}$ & $\begin{array}{l}\text { Common (coded) law countries are associated with higher } \\
\text { (lower) financial disclosures. For common law sample, } \\
\text { none of the cultural values seem to have any direct } \\
\text { significant influence on financial disclosures, but by the } \\
\text { information needs determined by ownership structure, } \\
\text { capital structure, and capital market. }\end{array}$ \\
\hline Studies by & $\begin{array}{l}\text { Independent (IV) and dependent variables (DV) of Corp. } \\
\text { Gov./Disclosure Metrics }\end{array}$ & Sample/Methods/Models & Empirical Results \\
\hline $\begin{array}{l}\text { Hope and Thomas (2008) } \\
\text { Examine the agency cost hypothesis } \\
\text { in the context of firms' decisions on } \\
\text { whether to disclose geographic } \\
\text { earnings in the annual report } \\
\text { following the adoption of Statement } \\
\text { of Financial Accounting Standards } \\
\text { No. 131 (SFAS 131, FASB } \\
\text { [1997])If nondisclosure of } \\
\text { geographic earnings reduces } \\
\text { monitoring of managerial actions, } \\
\text { then we expect to observe } \\
\text { managerial "empire building" (i.e., } \\
\text { an expansion of foreign operations), } \\
\text { reduced performance of foreign } \\
\text { operations, and an overall reduction } \\
\text { in firm value (Jensen [1986]). }\end{array}$ & $\begin{array}{l}\text { Test for the relation between Non-disclosure of geographic } \\
\text { earnings and foreign operations while controlling for } \\
\text { domestic operations and pre-SFAS } 131 \text { operations, Under } \\
\text { both foreign sales and domestic sales, DV's are the } \\
\text { five-year growth of sales, foreign profit margin and } \\
\text { Tobin's q in the post-SFAS } 131 \text { period. IV's are } \\
\text { performance of foreign operations proxied by dummy for } \\
\text { discloser or not, size, analyst follow, cross-listing, \# of line } \\
\text { of business (LOB), \% of shares held by institutional } \\
\text { shareholders, \% of shares held by the CEO, leverage, etc. }\end{array}$ & $\begin{array}{l}\text { From Compustat database, } 4,773 \text { firm-year } \\
\text { observation (from } 502 \text { firms) over } 10 \text { years } \\
\text { surrounding the adoption of SAFS } 131 \text { (i.e. five years } \\
\text { before and five years after adoption) were selected. } \\
\text { Observations that have two years of data in the } \\
\text { post-SFAS } 131 \text { period to more reliably classify firms } \\
\text { as disclosers and non-disclosers of geographic } \\
\text { earnings. } 2,263 \text { firm-year observations are } \\
\text { classified as disclosers of geographic earnings in the } \\
\text { post-SAFS 131 period and 2,510 observations in the } \\
\text { pre-SFAS } 131 \text { period. }\end{array}$ & $\begin{array}{l}\text { The results indicate a strongpositive relation between the } \\
\text { level of relational-investors ownership (\%INST) and } \\
\text { profitability ratios, as well as a strong, positive relation } \\
\text { between the portion of independentdirectors on the board } \\
\text { and profitability ratios, but no strong relation between the } \\
\text { portion ofinside directors or level of managerial } \\
\text { ownership and profitability in European companies. }\end{array}$ \\
\hline
\end{tabular}




\begin{tabular}{|c|c|c|c|}
\hline $\begin{array}{l}\text { V. Krivogorsky (2006) } \\
\text { Ownership, board structure, and } \\
\text { performancein continental Europe }\end{array}$ & $\begin{array}{l}\text { Three empirical proxies for performance are used in this } \\
\text { study: return on assets, return on equity, and } \\
\text { market-to-book value of the company. The first two } \\
\text { dependent variables are accounting rates of return on total } \\
\text { average assets and the book value of owners' equity for } \\
\qquad 2000 \text { and } 2001 . \\
\text { IV's are board structure: \% of independent directors, \% of } \\
\text { government representatives in the board, Ownership: } \\
\text { outside shareholder concentration, insider } \\
\text { ownership/power concentration, dummy for family-owned } \\
\text { and CEO, \% of ownership held by insiders managers on the } \\
\text { board, and dummy for CEO and chair of the board. }\end{array}$ & $\begin{array}{l}81 \text { companies from nine European countries, which } \\
\text { were members of the European Union in 1999. The } \\
\text { sample contained all companies from nine CEUM that } \\
\text { are traded consecutively on the NYSE during } 2000 \\
\text { and } 2001\end{array}$ & $\begin{array}{l}\text { Non-disclosure of geographic earnings is associated with } \\
\text { higher foreign sales growth and a decrease in foreign } \\
\text { profit margin. As monitoring is reduced, managers are } \\
\text { more willing to expand their international operations even } \\
\text { though it leads to lower profitability. Firm values are } \\
\text { consistently } \\
\text { lower for firms that no longer disclose geographic } \\
\text { earnings. This is consistent with investors perceiving these } \\
\text { managerial actions as value reducing as well. }\end{array}$ \\
\hline Studies by & $\begin{array}{l}\text { Independent (IV) and dependent variables (DV) of Corp. } \\
\text { Gov./Disclosure Metrics }\end{array}$ & Sample/Methods/Models & Empirical Results \\
\hline $\begin{array}{l}\text { Holm and Scholer (2010) } \\
\text { Reduction of Asymmetric } \\
\text { Information through Corporate } \\
\text { Governance Mechanisms-The } \\
\text { Importance of Ownership } \\
\text { Dispersion and Exposure toward } \\
\text { the International Capital Market. }\end{array}$ & $\begin{array}{l}\text { The IV's are proxies for exposure toward the international } \\
\text { capital market: extent of foreign shareholding, voluntary } \\
\text { IFRS adoption, \% of foreign board members, and extent of } \\
\text { international board member experience. While the DV's } \\
\text { are total disclosure level and proxy for board independence } \\
\text { that are tested against variables of ownership dispersion } \\
\text { and performance, risk and firm size. }\end{array}$ & $\begin{array}{l}100 \text { Danish companies listed on the Copenhagen Stock } \\
\text { Exchange in the } 2004 \text { annual reports, articles of } \\
\text { association, and company websites in } 2004 \text { and } 2005 . \\
\text { Use of linear regression (OLS) models to test the effect } \\
\text { on the corporate governance mechanisms through four } \\
\text { hypotheses with IV's (i.e. ownership dispersion, } \\
\text { exposure toward the international capital market, and } \\
\text { performance, risk and firm size. }\end{array}$ & $\begin{array}{l}\text { Transparency is a more important corporate governance } \\
\text { mechanism for firms with international capital market. } \\
\text { However, ownership dispersion differences do not affect } \\
\text { the use of the transparency mechanism. On the other hand, } \\
\text { board independence in the context of two-tier board } \\
\text { member system, not the international capital market, is an } \\
\text { important corporate governance mechanism in a widely } \\
\text { dispersed ownership. }\end{array}$ \\
\hline $\begin{array}{c}\text { Verriest, Gaeremynck and } \\
\text { Thornton (2010) } \\
\text { Corporate Governance and } \\
\text { Properties of IFRS Adoption }\end{array}$ & $\begin{array}{l}\text { The IV's are four sources of governance proxy: overall } \\
\text { GOVERNANCE: governance data developed by Risk } \\
\text { Metrics to measure corporate governance, functioning of } \\
\text { the board of directors (BFUNCTION), the independence of } \\
\text { the board of directors (BINDEP) and the quality and } \\
\text { effectiveness of the audit committee (AUDIT). } \\
\text { Regress IV's on DV: (i) RESTATEMENT. This is an } \\
\text { aggregate score capturing the quality and transparency of } \\
\text { companies' disclosure on the impact of first-time IFRS } \\
\text { application; (ii) DIFFSTAND, an aggregated disclosure } \\
\text { score capturing the amount and type of information firms } \\
\text { provide on } 6 \text { IFRS standards to investigate in detail } \\
\text { disclosure quality following IFRS standards; (iii) } \\
\text { EARLYADOP, a binary variable taking the value } 1 \text { for } \\
\text { firms early adopting IAS39 and } 0 \text { for firms postponing the } \\
\text { application of IAS39. }\end{array}$ & $\begin{array}{l}223 \text { firms across } 15 \text { countries sample contains all } \\
\text { companies belonging to the MSCI Pan Euro Index } \\
\text { between January } 1 \text { of } 2005 \text { and June } 30 \text { of } 2006 . \\
\text { Corporate governance data stem from the Risk Metrics } \\
\text { corporate database (formerly known as the Deminor } \\
\text { database) containing detailed corporate governance } \\
\text { information for all firms in the MSCI Pan Euro Index. } \\
\text { Additional financial data are obtained from World } \\
\text { scope } \\
\text { Lower (higher) values of each of these four } \\
\text { governance indicators to represent } 13 \text { weaker } \\
\text { (stronger) governance mechanisms, as they are } \\
\text { indicative to firms with a powerful and influential } \\
\text { management (board) over the board of directors } \\
\text { (management). } \\
\text { All corporate governance variables using data from } \\
\text { 2004, i.e. the year prior to the mandatory adoption of } \\
\text { IFRS which occurred in } 2005 \text {. }\end{array}$ & $\begin{array}{l}\text { Firms with strong corporate governance mechanisms } \\
\text { engage in higher financial reporting quality around the } \\
\text { moment of first-time IFRS adoption. Strong governance } \\
\text { firms disclose more extensive on specific IFRS disclosure } \\
\text { standards, use the timing adoption flexibility in a } \\
\text { significantly more conservative fashion than weak } \\
\text { governance firms. The weaker governance firms appear to } \\
\text { use this option mainly in an opportunistic fashion. Further, } \\
\text { better functioning boards, greater board independence and } \\
\text { more effective audit committees provide higher quality } \\
\text { information. }\end{array}$ \\
\hline Studies by & $\begin{array}{l}\text { Independent (IV) and dependent variables (DV) of Corp. } \\
\text { Gov./Disclosure Metrics }\end{array}$ & Sample/Methods/Models & Empirical Results \\
\hline $\begin{array}{c}\text { Aksu, M. (2006) } \\
\text { Transparency \& Disclosure in the } \\
\text { Istanbul Stock Exchange: Did IFRS } \\
\text { Adoption and Corporate } \\
\text { Governance Principles Make a }\end{array}$ & $\begin{array}{l}\text { Examine the relationship between Transparency \& } \\
\text { Disclosure (T\&D) scores \& firm-specific variables (size } \\
\text { measured by market value of equity, growth potential } \\
\text { measured by market-to-book-equity, leverage measured by } \\
\text { total liab. /total assets and firm performance measured by }\end{array}$ & $\begin{array}{l}\text { Use the database of T\&D scores in three categories for } \\
52 \text { large (based on market capitalization) and liquid } \\
\text { (based on trade volume) Turkish firms.in } 2003 \text { and } \\
2004 \text {. The objectives are to measure if firms T\&D } \\
\text { scores in } 2004 \text { is higher than } 2003 \text { due to IFRS }\end{array}$ & $\begin{array}{l}\text { Regression models show that firm performance, especially } \\
\text { market \& risk adjusted excess returns explain the variation } \\
\text { in TD Scores, IFRS adoption explains the variation in TD } \\
\text { Scores; \& IFRS adoption has a positive impact on the } \\
\text { relationship between performance \& TD Scores. In }\end{array}$ \\
\hline
\end{tabular}




\begin{tabular}{|c|c|c|c|}
\hline Difference? & $\begin{array}{l}\text { excess-returns and ROE), dummy for voluntary IFRS } \\
\text { adoption and years. }\end{array}$ & $\begin{array}{l}\text { adoption and committed themselves to a higher quality } \\
\text { governance and transparency. }\end{array}$ & $\begin{array}{l}\text { addition, firms with voluntary IFRS adoption is signaled } \\
\text { to commitment to transparency, full and reliable } \\
\text { disclosure, as it is strongly associated with the TD scores. }\end{array}$ \\
\hline $\begin{array}{l}\text { Durnev A. \& E. H. Kim (2005) } \\
\text { To Steal or Not to Steal: Firm } \\
\text { Attributes, Legal Environment, and } \\
\text { Valuation }\end{array}$ & $\begin{array}{l}\text { To test the hypotheses and conjectures concerning relations } \\
\text { between governance\& firm attributes, we regress } \\
\text { individual firms' corporate governance scores on measures } \\
\text { of investment opportunities, external financing needs, } \\
\text { ownership concentration, and legal environment, while } \\
\text { controlling for industry \&other firm characteristics. } \\
\text { The } D V \text { is } C O R P G O V \text { is corporate governance or } \\
\text { transparency scores; } \\
\text { INV OPP, investment opportunities; } E X T F I N \text {, the need for } \\
\text { external financing; } O W N C A S H \text {, concentration of cash flow } \\
\text { rights; and } L E G A L \text {, the strength of a country's legal } \\
\text { regime. Interaction terms } I N V O P P * L E G A L, E X T F I N \\
\text { *EEGAL, and } O W N C A S H * L E G A L \text { are those of the legal } \\
\text { regime with investment opportunities, external financing, } \\
\text { and ownership concentration, respectively. And } Z \text { 's are } \\
\text { control variables; } d \text {, industry dummy; } c \text {, country; } i, \\
\text { industry; } j, \text { firm; } K \text {, the number of control variables; and } I, \\
\text { the number of industries. }\end{array}$ & $\begin{array}{l}\text { CLSA issued a report on governance practices by } 494 \\
\text { companies in } 24 \text { countries providing scores on the } \\
\text { quality of governance in the year 2000. Firms are } \\
\text { selected based on size (large) and investor interest } \\
\text { (high). The governance scores are based on responses } \\
\text { from financial analysts to } 57 \text { questions that are used to } \\
\text { construct scores on a } 1 \text { to } 100 \text { scale, where a higher } \\
\text { number indicates better governance. } \\
\text { We interpret these scores as indicators of the quality of } \\
\text { disclosure practice. } \\
\text { If a firm has more disclosure on ownership-related } \\
\text { items, for example, we infer that the firm has less to } \\
\text { hide and hence has relatively sound practices on } \\
\text { matters concerning ownership structure. } \\
\text { The measure of the strength of legal environment is } \\
\text { based on regulation of measure of investor protection, } \\
\text { which is the anti-director rights (shareholder rights) } \\
\text { index. }\end{array}$ & $\begin{array}{c}\text { The results of regression with } I N V O P P \text { and } E X T F I N \text { as } \\
\text { IV's \&COMP, PROTECT, TRAN, and SOCIAL as } \\
\text { measures of the quality of governance. The results are } \\
\text { supportive of our hypotheses. Both investment } \\
\text { opportunities\&external financing are significantly } \\
\text { positively related to the composite index and investor } \\
\text { protection. The strength of legal regimes, } L E G A L \text {, is also } \\
\text { positively related to both scores. } \\
\text { The interaction terms of the legal regime with investment } \\
\text { opportunities \&external financing for } C O M P \text { and } \\
\text { PROTECT show negative coefficients, \&three of four are } \\
\text { significant. These results are consistent with the } \\
\text { hypotheses that positive relations for investment } \\
\text { opportunities \&external financing are stronger in weaker } \\
\text { legal environments. }\end{array}$ \\
\hline Studies by & $\begin{array}{l}\text { Independent (IV) and dependent variables (DV) of Corp. } \\
\text { Gov./Disclosure Metrics }\end{array}$ & Sample/Methods/Models & Empirical Results \\
\hline $\begin{array}{l}\text { Jiang and Shan (2013) } \\
\text { Do Corporate Governance } \\
\text { Mechanisms Impact on Earnings } \\
\text { Quality? Evidence from IFRS } \\
\text { Adoption in the UK and Germany. }\end{array}$ & $\begin{array}{l}\text { To study primarily explores the impact of International } \\
\text { Financial Reporting Standards mandatory adoption on } \\
\text { accruals quality in the United Kingdom and Germany from } \\
2001 \text { to } 2009 \text {, the research questions are (i) if accounting } \\
\text { standards as the sole determinant of earnings quality; (ii) if } \\
\text { accounting standards and preparer incentives as } \\
\text { determinants of earnings quality; \& (iii) if Anglo-American } \\
\text { shareholder-oriented model (European Continental or } \\
\text { German-Japanese stakeholder-oriented model) is (not) } \\
\text { significantly associated with accrual quality. }\end{array}$ & $\begin{array}{l}\text { Sample data was taken from years 2001-2004as the } \\
\text { pre-mandatory adoption period and years 2005-2009 } \\
\text { as the post-mandatory adoption period. Specifically, } \\
\text { sample was selected according to market capitalisation } \\
\text { of firms listed on the UK FTSE } 100 \text { and top German } \\
\text { stock exchanges (i.e., DAX, TecDAX and MDAX). } \\
\text { Accounting data are retrieved from the Worldscope } \\
\text { database. Corporate governance data are manually } \\
\text { collected from company annual reports. Consistent } \\
\text { with prior literature, financial institutions are excluded } \\
\text { in the sample due to different regulation and disclosure } \\
\text { requirements (Aharony et al., 2010; Chen et al., 2010). } \\
\text { Also, a panel data set has been constructed, consisting } \\
\text { of } 36 \text { UK firms with } 324 \text { firm-year observations and } \\
37 \text { German firms with } 333 \text { firm-year observations. } \\
\text { Earnings quality is operationalized by accruals quality } \\
\text { metric for all three regression models. }\end{array}$ & $\begin{array}{l}\text { Consistent with Chen et al. (2010), the results indicate that } \\
\text { firms in the post-adoption period exhibit higher accruals } \\
\text { quality. A firm with less earnings management incentives } \\
\text { as signalled by effective CGMs (i.e., higher } C G S \text { ) is } \\
\text { expected to have higher accruals quality (i.e., lower } A Q \\
\text { measure). It suggests higher accruals quality for firms with } \\
\text { effective CGMs, which is consistent with the prediction } \\
\text { However, the improvement on accruals quality is not } \\
\text { solely driven by IFRS adoption; effective CGMs also } \\
\text { significantly affect accruals quality. More importantly, the } \\
\text { role of effective CGMs in accruals quality in the UK } \\
\text { significantly differs from it in Germany. In the UK, CGMs } \\
\text { and IFRS jointly impact on accruals quality. Furthermore, } \\
\text { in the presence of effective corporate governance, the } \\
\text { demand for high quality accounting standards (i.e., IFRS) } \\
\text { for the purpose of improving accruals quality is less } \\
\text { significant than it in the case where corporate governance } \\
\text { is absent. On the contrary, in Germany, evidence on the } \\
\text { rigid demand for high quality standards is documented, } \\
\text { irrespective of the effectiveness of corporate governance. }\end{array}$ \\
\hline
\end{tabular}




\section{REFERENCES}

[1] Aksu, M. 2006. Transparency \& Disclosure in the Istanbul Stock Exchange: Did IFRS Adoption and Corporate Governance Principles Make a Difference? Working Paper Series, available at http://ssrn.com/abstract $=965301$.

[2] Ashbaugh H., D.W. Collins, \& R. LaFond. 2004. Corporate Governance and the Cost of Equity Capital, Working Paper Series, available at SSRN: http://ssrn.com/abstract=639681 or http://dx.doi.org/10.2139/ssrn.639681

[3] Ball R., A. Robin \& J. Wu. 2003. Incentives versus standards: properties of accounting income in four East Asian countries, Journal of Accounting \& Economics, 39: 83-128.

[4] Barth, M.E. 2006. Standard-setting measurement issues and the relevance of research, Accounting and Business Research, 37: 7-15.

[5] Berle, A., \& G. Means. 1932. The Modern Corporate and Private Property, New York: Macmillan (ed.1969, New York: Hardcourt, Brace \& World).

[6] Beyer, A., D. Cohen, T. Lys \& B.R. Walther 2005. The Financial Reporting Environment: Review of the Recent Literature, Working Paper, available at: http://ssm.com/abstract $=1483227$.

[7] Cadbury. A. (1992). Report of the Committee on the Financial Aspects of Corporate Governance. London: Gee and $\mathrm{Co}$

[8] Daske H., L. Hail, C. Leuz \& R. Verdi, 2008. Mandatory IFRS Reporting around the World: Early Evidence on the Economic Consequences, Journal of Accounting Research, 46: $1085-1142$.

[9] Diamond, D. \& Verrecchia, R. 1991. Disclosure, Liquidity and the Cost of Capital, Journal of Finance, 46: 1325-1360.

[10] Durnev A. \& E. H. Kim 2005. To Steal or Not to Steal: Firm Attributes, Legal Environment, and Valuation, The Journal of Finance, Vol. LX, 3, 1461-1493.

[11] Dwivedi, N. \& Jain, A. K. 2005. Corporate governance and performance of Indian firms: The effect of board size and ownership. Employee Responsibilities and Rights Journal, 17: 161-172.

[12] Dye, R.A. \& Sridhar, S.S. 2008. A positive theory of flexibility in accounting standards. Journal of Accounting and Economics, 46, 312-333.

[13] Gani, L. \& Jermias, J. 2006. Investing the effect of board independence on performance across different strategies. The International Journal of Accounting, 41: 295-314.

[14] Gorton, G. \& Schmid, F. 1999. Corporate governance, ownership dispersion and efficiency: Empirical evidence from Austrian cooperative banking. Journal of Corporate Finance, 5: 119-140.

[15] Gray, S.J., Meek, G.K., \& Roberts, C. B. 1995. International capital market pressures and voluntary annual report disclosures by U.S. and U.K. multinationals. Journal of International Financial Management \& Accounting, 6 (1): 43-69.
[16] Holm, C., \& Scholer, F. 2010. Reduction of Asymmetric Information Through Corporate Governance Mechanism The Importance of Ownership Dispersion and Exposure toward the International Capital Market. Corporate Governance: An International Review, 18 (1): 32-47.

[17] Hope, O-K \& W. Thomas. 2008. Managerial empire building and firm disclosure, Journal of Accounting Research, 46, 591-626.

[18] International Organization of Securities Commissions (IOSCO), 2000. A resolution on IASC standards: presidents' Committee of OSCO. Madrid, Spain: IOSCO.

[19] Jaggi, B. and P.Y. Low. 2000. Impact of Culture, Market Forces, and Legal System on Financial Disclosures", The International Journal of Accounting, Vol. 35, No. 4. Jensen, M.C. \& Meckling, W. H. 1976. Theory of the firm: Managerial behavior, agency cots and ownership structure. Journal of Financial Economics, 3: 305-360.

[20] Klein, P., Shapiro, D., \& Young, J. 2005. Corporate governance, family ownership, and firm value: The Canadian evidence. Corporate Governance: An International Review, 13: 769 .

[21] Krivogorsky, V. 2006. Ownership, board structure, and performance in continental Europe. International Journal of Accounting, 41: 176-198.

[22] Lambert, R., C. Leuz, and R. Verrecchia, 2007. Accounting information, disclosure, and the cost of capital, Journal of Accounting Research, 45 (2): 385-420.

[23] Leuz, C. \& Verecchia, R. E., 2000. The economic consequences of increased disclosure. Journal of Accounting Research, 38: 91-124.

[24] Liang, J. \& Y. G. Shan. 2013. Do Corporate Governance Mechanisms Impact on Earnings Quality? Evidence from IFRS Adoption in the UK and Germany, Working Paper series Available at SSRN: http://ssrn.com/abstract=2190329 or http://dx.doi.org/10.2139/ssrn.2190329

[25] OECD 2004. Principles of Corporate Governance. OECD Publications Service. Paris: Organization for Economic Cooperation and Development.

[26] Rezaee, A. 2009. Corporate Governance and Ethics, Wiley, U.S.

[27] Shan, Y.G. and L. Xu. 2012. Bad debt provisions of financial institutions: dilemma of China's corporate governance regime, International Journal of Managerial Finance, 8 (4): 344-364.

[28] Shleifer, A.\& Wolfenzon, D. 2002. Investor protection and equity markets. Journal of Financial Economics, 66, 3-27.

[29] Soderstrom, N. \& K.J. Sun. 2007. IFRS adoption and accounting quality: a review, European Accounting Review, 16(4): 675-702.

[30] Verriest A., Gaeremynck A., \& Thornton D.B. 2010. Corporate governance and properties of IFRS adoption. INTACCT Working Paper. Tilburg University, electronic copy available at://ssm.com/abstract=1266698.

[31] Zarzeski, M.T. 1996. Spontaneous Harmonization Effects of Culture and Market Forces on Accounting Disclosure Practices, Accounting Horizons, Vol. 10, No. 1, 1996. 